\title{
Electrical Resistivity Sounding for Groundwater Investigation around Enugu Metropolis and the Environs, Southeast Nigeria
}

\author{
Claris C. Nwachukwu ${ }^{1}$, Charles C. Ugbor ${ }^{1 *}$, Osim Jethro Ogboke ${ }^{2}$ \\ ${ }^{1}$ Department of Geology, University of Nigeria, Nsukka, Enugu State, Nigeria \\ ${ }^{2} \mathrm{NNPC}$, Lagos, Nigeria \\ Email: *charles.ugbor@unn.edu.ng
}

How to cite this paper: Nwachukwu, C.C., Ugbor, C.C. and Ogboke, O.J. (2022) Electrical Resistivity Sounding for Groundwater Investigation around Enugu Metropolis and the Environs, Southeast Nigeria. International Journal of Geosciences, 13, 54-70. https://doi.org/10.4236/ijg.2022.131004

Received: September 26, 2021

Accepted: January 26, 2022

Published: January 29, 2022

Copyright $\odot 2022$ by author(s) and Scientific Research Publishing Inc. This work is licensed under the Creative Commons Attribution International License (CC BY 4.0).

http://creativecommons.org/licenses/by/4.0/

\begin{abstract}
This report evaluates the use of electrical method and borehole data to investigate the subsurface to delineate the groundwater potential in Enugu metropolis and the environs, south-eastern Nigeria other than rely only on resistivity method which could lead to interpretation error. Integrating these 2 data sets is key in this study. The study area is located in the Anambra Basin and is underlain by Nkporo/Enugu Shale which is overlain by the Mamu Formation. It is bounded by Latitudes $6^{\circ} 20^{\prime} 00^{\prime \prime} \mathrm{N}$ to $6^{\circ} 30^{\prime} 00^{\prime \prime} \mathrm{N}$ and Longitudes $7^{\circ} 25^{\prime} 00^{\prime \prime} \mathrm{E}$ to $7^{\circ} 35^{\prime} 00^{\prime \prime} \mathrm{E}$ and covers surface area of about $342 \mathrm{~m}^{2}$. Thirty-one vertical electrical soundings (VES) were carried out across the area using the Schlumberger electrode array with current electrode separation from 2 to 500 $\mathrm{m}$ to identify the depths and resistivity values of the identified geo-electric layers. Through data analysis using WinResist software, the apparent resistivity, thicknesses and depths and the thicknesses of the aquifers were generated. The resistivity and depths were modelled to generate resistivity map and depth map. The resistivity of the aquiferous zone within the study area varied from $20.55-427.8 \mathrm{ohm}-\mathrm{m}$ at depths of between $10.7-40.05 \mathrm{~m}$. Depth to the water table appears to be shallow at the south western part of the map. The interpreted geo-electric layers show a sequence of lateritic top soil, shale, sand and shale. The frequency distribution of the VES curves generated shows the presence of 3 to 5 layers with HK type as the highest. Also, a 2D model was generated using the correlation of VES to VES data and borehole data to VES data to show the underlying stratigraphy beneath the study area as well as the direction of ground water flow. Result of the VES curve analysis reveals that the sub-surface is underlain by three lithological layers namely: lateritic top soil, shale, sand and shales with NW direction of groundwater flow from the 2D model. Groundwater prospective zones can be seen along NW, SW and
\end{abstract}


central parts of the study area which have low resistivity values.

\section{Keywords}

Electrical Method, Vertical Electrical Sounding, Groundwater, Aquifer, Apparent Resistivity

\section{Introduction}

Groundwater is water that exists underground in saturated zones beneath the land surface. It fills the pores and fractures in underground materials such as sand, gravel, and other rock where it is stored in and moves slowly through geologic formations like porous and permeable rocks called aquifers like sandstones or porous but impermeable rocks called aquicludes like shale. Groundwater is a vital resource of nature and is stored in the subsurface. The principle of detecting the existence of groundwater in saturated layers in the subsurface had been clearly explained by the early authors such as [1] [2] [3] and [4] among others. The demand for water over decades has greatly increased and its exploitation for adequate usage has become a thing of worry and necessity. Enugu Metropolis and the environs are underlain primarily by impermeable rocks, with only isolated regions having interlayering of sandstones [5]. This makes sourcing of water in the area highly problematic. This is so as the city is the capital city of Enugu state, which makes the place an urban city with teaming population that requires water for wide range of applications including domestic and industrial purposes. There is therefore increasing need to carry out detailed study of the subsurface to identify potential areas for groundwater accumulation to be able to meet the needs to the populace. Following the increasing population and inaccessibility of groundwater in the area, there is need to explore for groundwater potential in order to meet the need of the populace in the area. To achieve this, we must have a reliable estimate of groundwater potential by integrating data from different methods. This has routinely been done using borehole and geophysical method. This helps to understand the nature and distribution of the different rock layers in the subsurface that could be storage locations for the groundwater. Geophysical methods among others are powerful tools to study and acquire very good information about the aquifer [6]. The geophysical methods provide information about the aquifer's resistivity, thickness and distribution. The electrical resistivity has been used because of its relatively high diagnostic values and simplistic technical nature. A relatively inexpensive way to prospect for groundwater, both on a small and large scale is by using electrical resistivity method of geophysical prospecting; this method is fast, repeatable, relatively cheap and non-intrusive, thus making it a practical alternative to traditional approaches. Reference [7] had successfully characterized the aquifer properties in the Cenonian aquifer in central Sinai, Egypt by combining the re- 
sults from vertical electrical sounding and transient electromagnetic data. In the same vein, reference [8] employed the vertical electrical sounding method to investigate the groundwater potential at Nsukka L.G.A of Enugu state, Nigeria. Their result shows that the method was useful in determining the thickness of saturated layers in the area from the variations in the resistivity. Also, reference [9] employed the electrical resistivity method to carry out a hydrostratigraphic and hydrogeology study of western part of Maira area in Pakistan. A regression curve relation between the results from the electrical sounding and the pumping test proved that the electrical method a good tool in aquifer characterization. In 2013, reference [10] adopted the principle of electrical resistivity sounding method in their aquifer hydraulics studies and was able to delineate groundwater quality zones as low, very low and negligible potential zones using electrical resistivity method at Oduma and environs in Enugu State. In 2013, reference [11] used the electrical resistivity method to identify the resistivity, thicknesses of the different layers, hence infer the aquifers in the area. Also the borehole log was used to correlate some VES in the study area to identify the direction of groundwater flow since VES is able to map the subsurface structures and lithologic variations at satisfactory depth. Similarly In 2014, reference [12] studied the groundwater potential at Lokpaukwu, Abia state using electrical resistivity method proving its potency in determining the water table at different depth proving the potential of the resistivity method in determining the groundwater occurrence in an area. Reference [13] used electrical resistivity method to determine the aquifer characteristics in parts of Anambra state. They successfully delineated the aquifer layers and estimated the aquifer characteristics by applying both curve matching and computer-aided software interpretation. Also, [14] used the electrical sounding method to evaluate the aquifer potential and successfully characterized the aquifer on the basis of the hydraulic conductivities. [15] also applied the vertical electrical sounding method to successfully explore for groundwater in Onitsha and the environs and were able to identify areas that can produce sustainable water supply. Similarly, reference [16] adopted the principle of vertical electrical sounding technique and successfully determined the groundwater prospects in Awgu and the environs in Enugu state, southeastern Nigeria. [17] similarly successfully employed the electrical resistivity sounding method to assess the groundwater potential at Ewuloja and its environs, southwestern Nigeria. Reference [18] also employed a combination of direct current electrical resistivity method with pumping test data in their investigation of groundwater. Interpretation using FORTRAN Resistivity 2D Inverse computer program were able to delineate the subsurface layers and identify saturated areas occupied by groundwater. In 2019, Reference [19] utilized a geoelectrical sounding technique and determined the groundwater potential aquifer zones in Anambra state. The current research is therefore to combine the electrical resistivity sounding method together with borehole data to properly characterize the subsurface with a view to identifying areas of better potential for groundwater. 


\subsection{Location and Accessibility}

The study area, Enugu metropolis and environs, is located within the Anambra Basin, southeastern Nigeria. It is bounded by Latitudes $6^{\circ} 20^{\prime}$ to $6^{\circ} 30^{\prime}$ North of the equator and Longitudes $7^{\circ} 25^{\prime}$ to $7^{\circ} 35^{\prime}$ East of the Greenwich Meridian (Figure 1). The project area can be accessed through roads and footpaths. A major road from Ngwo in Enugu North through to Abakpa Nike to Nchatancha can lead to the study area. Paths linking villages, streams and farmlands also exist in the study area. Figure 1 shows the location and accessibility map of the study area.

\subsection{Geology of the Study Area}

The study area lies on the geologic formation referred to as Anambra Basin which is at the flank of Benue Trough. The lithology comprises dark gray, often friable shales with occasional thin beds of limestone and sandstone. The type locality is Nkporo town and it is of shallow marine origin with a thickness of about 150 metres. The Owelli Sandstone, Enugu Shale/Asata Shale are lateral equivalents of the Nkporo Shale. Figure 2 is the geology map of the study area.

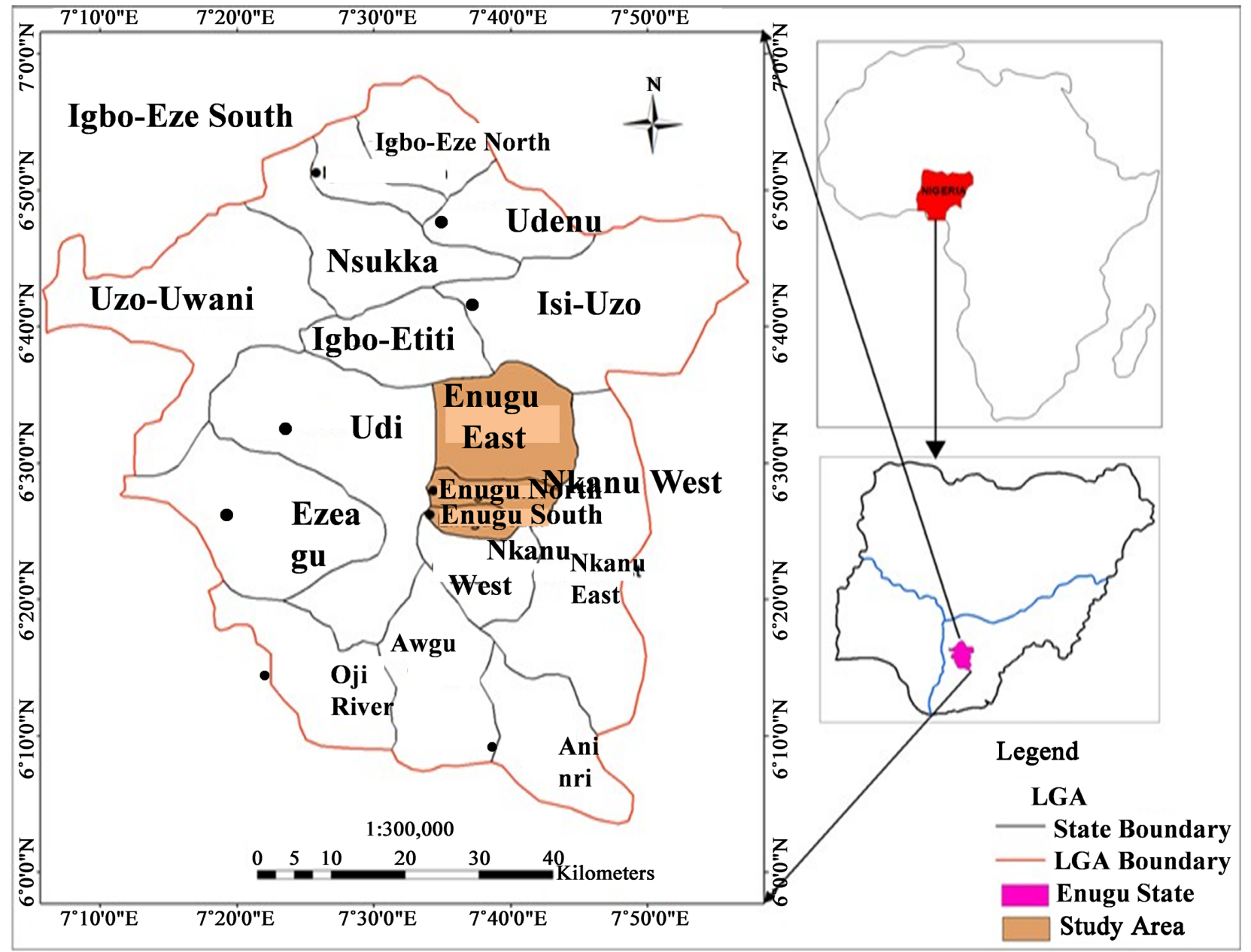

Figure 1. Location map of the study area. 


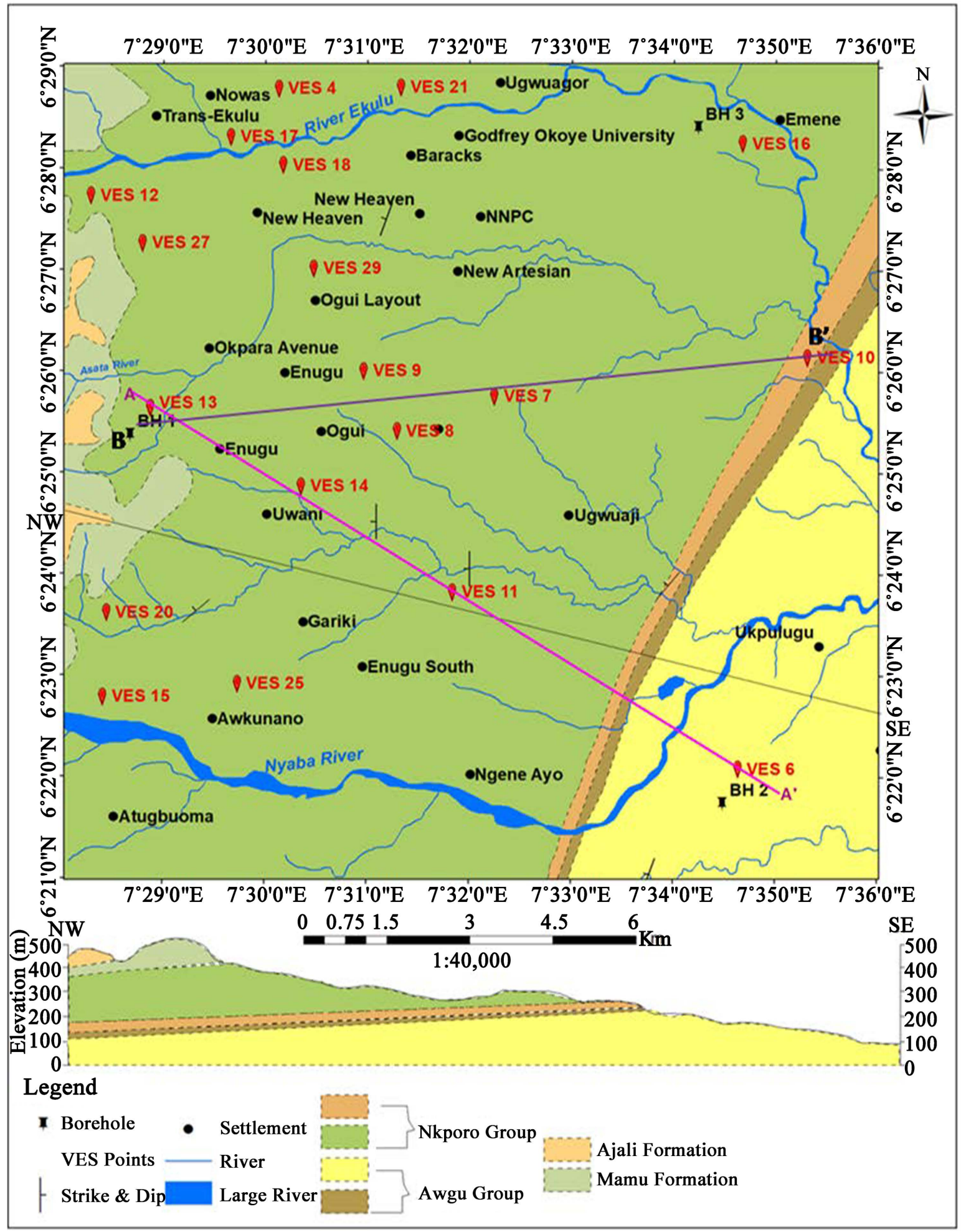

Figure 2. Geologic Map of the Study Area.

\section{Material and Methods}

The resistivity data were obtained from field data acquisition using Abem Terameter using the Schlumberger array method. The two current carrying electrode 
were used to introduce current into the ground. The responses of the underlying materials were recorded by the two potential electrodes. The data collected were analyzed using Win Resist software to generate the apparent resistivity and thicknesses of the layers. The resistivity of the model blocks is adjusted iteratively until the calculated apparent resistivity values of the model agrees with the actual measurement [20]. VES surveys were performed to obtain deeper measurements and increasing the separation of the current electrodes increases the depth of current penetration, which allows for a deeper depth of investigation as seen in Figure 3. In a VES using the Schlumberger array, the effective depth of penetration is generally $20 \%-40 \%$ that of the outer electrode spacing (AB), dependent on the earth resistivity structure. The current flow and equi-potentials are distorted as they pass from one resistivity medium to another. VES is useful in determining the depth of overburden, thickness, structure, and resistivity of flat-lying sedimentary beds and possibly the basement, if it is not too deep [3]. The data collected were analyzed to generate the sounding curves of the layers in the area.

Where $\mathrm{AB}$ and $\mathrm{MN}$ are current and potential electrodes respectively [2], a multilayer resistivity model consists of layer apparent resistivity, thickness and depth. Borehole logs were obtained from borehole drilling in the study area by private drillers and correlated with some VES to generate the 2D model showing the stratigraphy of the study area and groundwater flow direction.

\section{Field Data Acquisition}

Thirty one vertical electrical soundings (VES) were carried out across the area

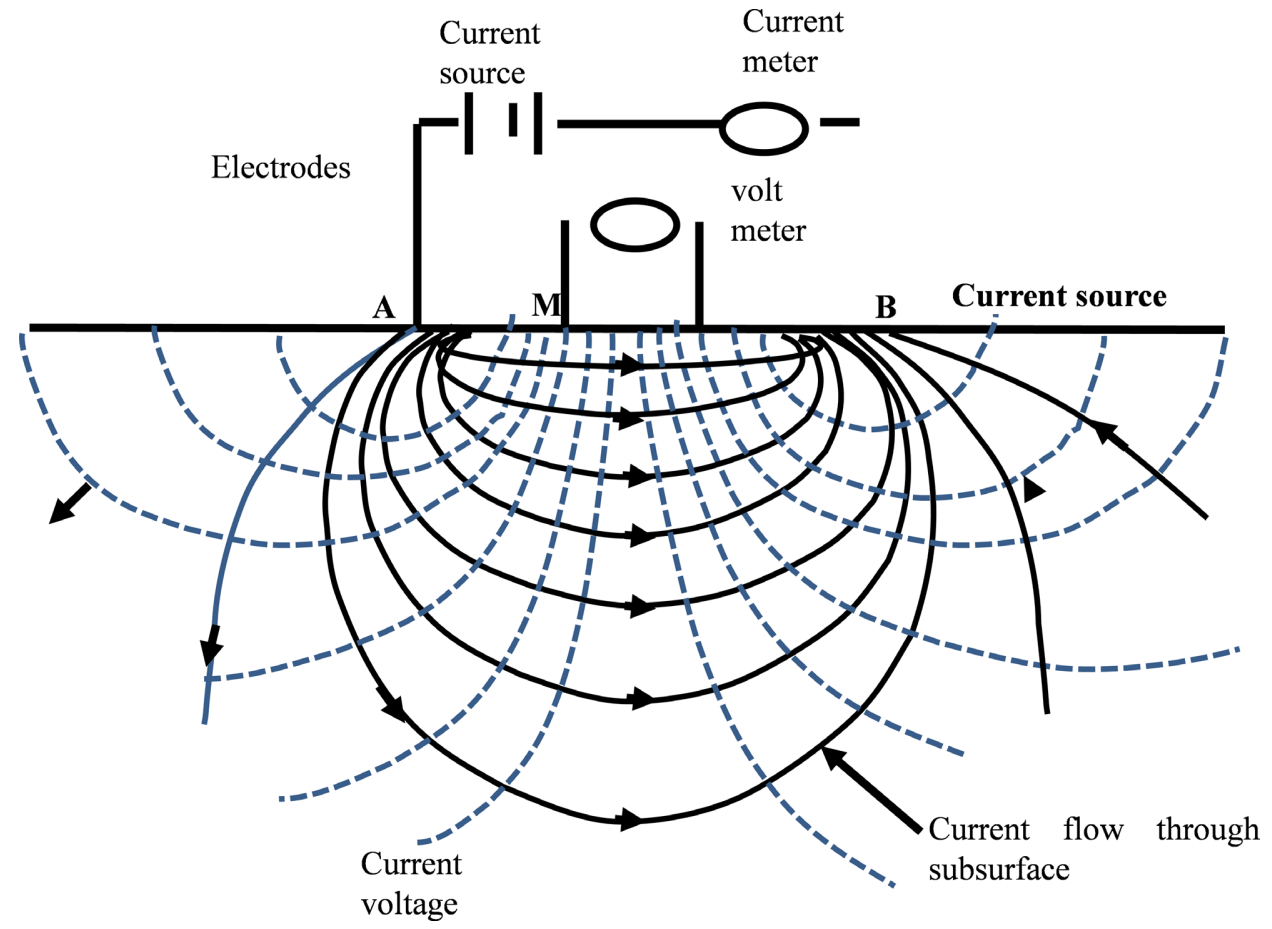

Figure 3. Current flow pattern. 
using the Schlumberger electrode array configuration with current electrode separation $(\mathrm{AB})$ varying from 2 to $500 \mathrm{~m}$ to identify the various geo-electric layers under laying the study area accompanied by their respective depths and resistivity values. The depth to water and resistivity of the aquiferous zones beneath each VES station were further modelled to generate depth and resistivity maps of the area. After acquiring the data, the measured field resistance $(\mathrm{R})$ in ohms was converted to apparent resistivity $\left(\rho_{\mathrm{a}}\right)$ in ohm-meter by multiplying resistance $(\mathrm{R})$ by the geometric factor $(K)$. A log-log graph plot of apparent resistivity $\left(\rho_{a}\right)$ against current electrode distance $(\mathrm{AB} / 2)$ was plotted for each VES station to generate a sounding curve as seen in Figures 4-8. The table of some resistivity values and thicknesses of the VES are shown on Table 1 and Table 2.

Table 1. Field Data VES; 1-5.

\begin{tabular}{|c|c|c|c|c|c|c|c|}
\hline \multicolumn{3}{|c|}{ VES S/N } & \multirow{2}{*}{$\begin{array}{c}\text { VES } 1 \\
\rho \mathrm{a}\end{array}$} & \multirow{2}{*}{$\begin{array}{c}\text { VES } 2 \\
\rho \mathrm{a}\end{array}$} & \multirow{2}{*}{$\begin{array}{c}\text { VES } 3 \\
\rho \mathrm{a}\end{array}$} & \multirow{2}{*}{$\begin{array}{c}\text { VES } 4 \\
\rho \mathrm{a}\end{array}$} & \multirow{2}{*}{$\begin{array}{c}\text { VES } 5 \\
\rho \mathrm{a} \\
\text { HalfSchlumberger }\end{array}$} \\
\hline$S / N$ & $\mathrm{AB} / 2$ & $\mathrm{MN} / 2$ & & & & & \\
\hline 1 & 1.5 & 0.5 & 2.0133 & 173.3928 & 53.97583 & 228.1037 & 14.1372 \\
\hline 2 & 2 & 0.5 & 1.8488 & 221.9226 & 64.83006 & 233.358 & 47.124 \\
\hline 3 & 3 & 0.5 & 2.39 & 291.1871 & 81.83868 & 321.0323 & 117.81 \\
\hline 4 & 5 & 0.5 & 2.7766 & 399.5173 & 93.24897 & 319.5007 & 247.401 \\
\hline 5 & 8 & 0.5 & 3.516 & 648.1859 & 101.06528 & 689.7383 & 194.3865 \\
\hline 6 & 10 & 0.5 & 3.2932 & 704.2769 & 123.05018 & 984.4015 & 128.1773 \\
\hline 7 & 15 & 0.5 & 3.8124 & 854.3787 & 163.13885 & 557.9482 & 313.3746 \\
\hline 8 & 15 & 3.5 & 4.0484 & 892.8758 & 171.1544 & 104.1205 & 158.8668 \\
\hline 9 & 20 & 3.5 & 3.7144 & 155.9131 & 58.16448 & 316.9762 & 306.9071 \\
\hline 10 & 30 & 3.5 & 3.972 & 226.3747 & 90.08314 & 351.6797 & 994.4126 \\
\hline 11 & 40 & 3.5 & 4.314 & 345.2955 & 95.1456 & 410.3715 & 245.5377 \\
\hline 12 & 50 & 3.5 & 4.059 & 448.3512 & 101.1012 & 513.3823 & 512.2571 \\
\hline 13 & 50 & 14 & 3.6907 & 713.0534 & 128.48107 & 612.5222 & 162.8759 \\
\hline 14 & 75 & 14 & 4.8546 & 874.3746 & 162.316 & 663.663 & 398.7508 \\
\hline 15 & 100 & 14 & 6.2297 & 203.8394 & 66.5346 & 334.0755 & 230.8114 \\
\hline 16 & 150 & 14 & 8.906 & 440.5253 & 118.4622 & 480.9173 & 122.3706 \\
\hline 17 & 200 & 14 & 10.593 & 751.4034 & 109.9784 & 779.229 & 392.8603 \\
\hline 18 & 200 & 42 & 9.5256 & 762.60938 & 130.49825 & 1698.953 & 966.0345 \\
\hline 19 & 300 & 42 & 13.483 & 775.99230 & 242.0996 & 1355.657 & 201.0945 \\
\hline 20 & 400 & 42 & 14.05 & 958.50857 & 240.5568 & 1915.478 & 638.0013 \\
\hline 21 & 500 & 42 & 15.823 & 878.95769 & 240.60666 & 157.08 & 680.965 \\
\hline 22 & 600 & 42 & 12.33 & 682.01061 & 299.20 & 385.6875 & 169.0124 \\
\hline
\end{tabular}


Table 2. Field Data VES 6-11.

\begin{tabular}{|c|c|c|c|c|c|c|c|c|}
\hline \multicolumn{3}{|c|}{ VES S/N } & \multirow{2}{*}{$\begin{array}{c}\text { VES } 6 \\
\rho \mathrm{a}\end{array}$} & \multirow{2}{*}{$\begin{array}{c}\text { VES } 7 \\
\rho \mathrm{a}\end{array}$} & \multirow{2}{*}{$\begin{array}{c}\text { VES } 8 \\
\rho a\end{array}$} & \multirow{2}{*}{$\begin{array}{c}\text { VES } 9 \\
\rho a\end{array}$} & \multirow{2}{*}{$\begin{array}{c}\text { VES } 10 \\
\rho \mathrm{a}\end{array}$} & \multirow{2}{*}{$\begin{array}{c}\text { VES } 11 \\
\rho a\end{array}$} \\
\hline $\mathrm{S} / \mathrm{N}$ & $\mathrm{AB} / 2$ & $\mathrm{MN} / 2$ & & & & & & \\
\hline 1 & 1.5 & 0.5 & 49.12677 & 331.0932 & 331.0932 & 375.1306 & 380.6441 & 1357.878 \\
\hline 2 & 2 & 0.5 & 126.795 & 238.8873 & 238.8873 & 314.7883 & 446.4842 & 1328.268 \\
\hline 3 & 3 & 0.5 & 142.5108 & 333.5987 & 333.5987 & 179.0123 & 492.8385 & 1347.354 \\
\hline 4 & 5 & 0.5 & 149.2606 & 371.8084 & 371.8084 & 166.0273 & 514.594 & 1384.88 \\
\hline 5 & 8 & 0.5 & 185.5115 & 519.3065 & 519.3065 & 118.6739 & 767.8072 & 1019.449 \\
\hline 6 & 10 & 0.5 & 229.2111 & 560.1598 & 560.1598 & 61.56531 & 618.882903 & 711.962 \\
\hline 7 & 15 & 0.5 & 280.325 & 519.9348 & 519.9348 & 33.30096 & 779.015484 & 538.1561 \\
\hline 8 & 15 & 3.5 & 286.8438 & 549.4423 & 549.4423 & 19.28314 & 790.743548 & 410.7563 \\
\hline 9 & 20 & 3.5 & 226.2962 & 487.2285 & 487.2285 & 26.61833 & 585.519548 & 316.3703 \\
\hline 10 & 30 & 3.5 & 308.0563 & 286.3344 & 286.3344 & 9.758707 & 638.807895 & 438.7469 \\
\hline 11 & 40 & 3.5 & 430.6797 & 144.6819 & 144.6819 & 10.60851 & 605.88 & 158.1459 \\
\hline 12 & 50 & 3.5 & 529.943 & 84.37889 & 84.37889 & 12.28725 & 525.4999 & 54.0445 \\
\hline 13 & 50 & 14 & 746.0851 & 30.22399 & 30.22399 & 28.47187 & 437.3107 & 29.56335 \\
\hline 14 & 75 & 14 & 857.3202 & 19.25352 & 19.25352 & 18.08664 & 408.2958 & 41.87304 \\
\hline 15 & 100 & 14 & 860.574 & 25.56758 & 25.56758 & 15.94082 & 39.80295 & 110.3487 \\
\hline 16 & 150 & 14 & 795.8486 & 21.149 & 21.149 & 23.61039 & 54.01799 & 99.40219 \\
\hline 17 & 200 & 14 & 373.7382 & 28.76808 & 28.76808 & 15.61824 & 60.96636 & 95.35878 \\
\hline 18 & 200 & 42 & 306.0956 & 51.83991 & 51.83991 & 18.88116 & 56.53828 & 69.31856 \\
\hline 19 & 300 & 42 & 119.9138 & 56.29635 & 56.29635 & 86.48937 & 52.48436 & 200.4453 \\
\hline 20 & 400 & 42 & 20.20498 & 70.0906 & 110.0906 & 162.4207 & 63.23592 & 436.1887 \\
\hline 21 & 500 & 42 & 27.6012 & 56.36104 & 46.36104 & 291.2712 & 102.3713 & 55.21736 \\
\hline 22 & 600 & 42 & 21.92575 & 61.10225 & 61.10225 & 34.595 & 73.2105 & 26.53063 \\
\hline
\end{tabular}

\section{Data Interpretation}

The interpretation was done using the thickness, resistivity values of the geo-electric units curve types generated. The interpreted VES data and their results are shown in Figures 4-8.

\subsection{Resistivity Data Analysis and Interpretation}

Data interpretation included analyses of the subsurface layers based on the variation of the geo-electric layers from the vertical electrical sounding data. The WinResist software was employed for the analysis of the variation of the apparent resistivities over various penetration depths. The apparent resistivity (AR) values generated were used to plot against the half-current spacing's on log-log graph to generate the field curves using the WinResist software. The software 


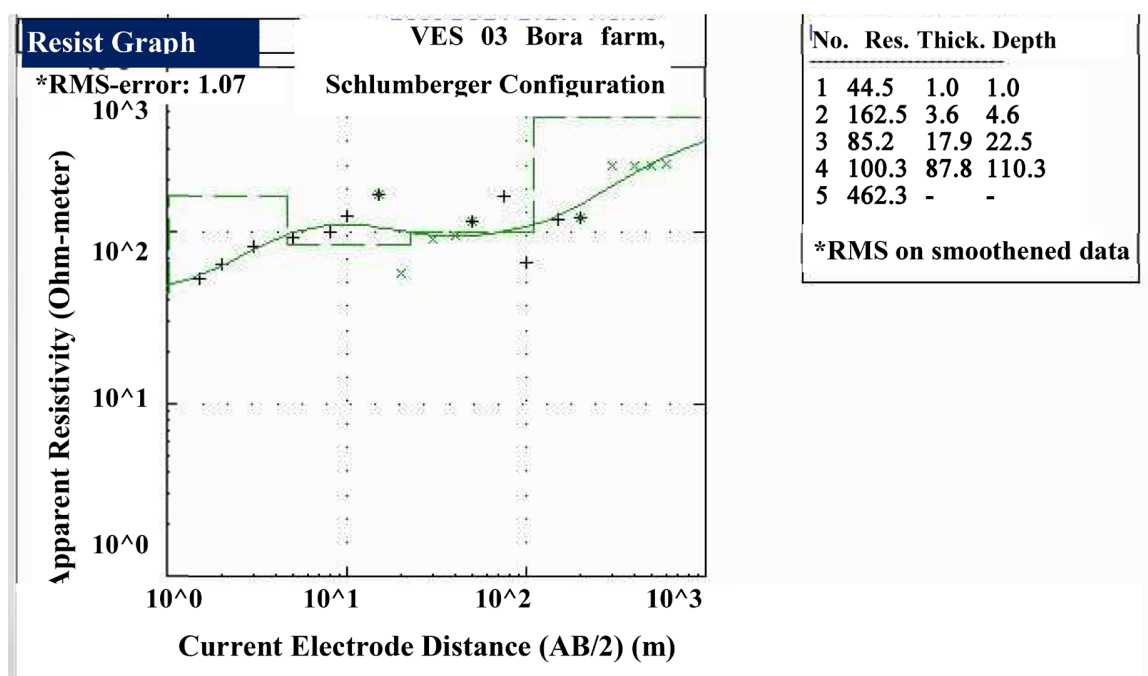

Figure 4. Interpretation curve for VES 3.

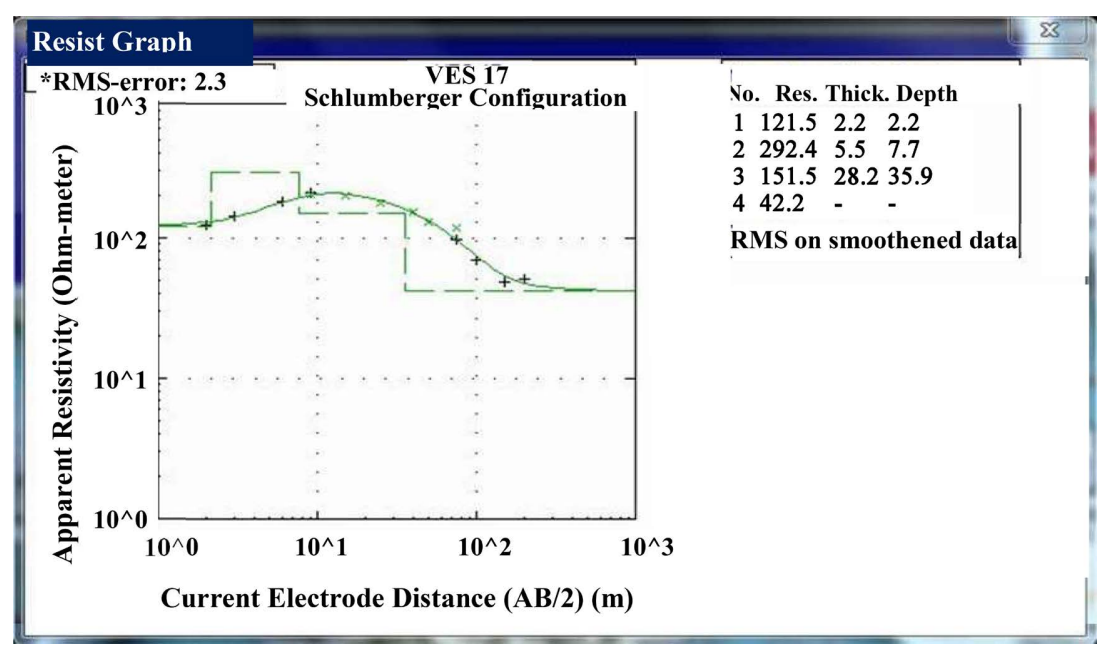

Figure 5. Interpretation curve for VES 17.

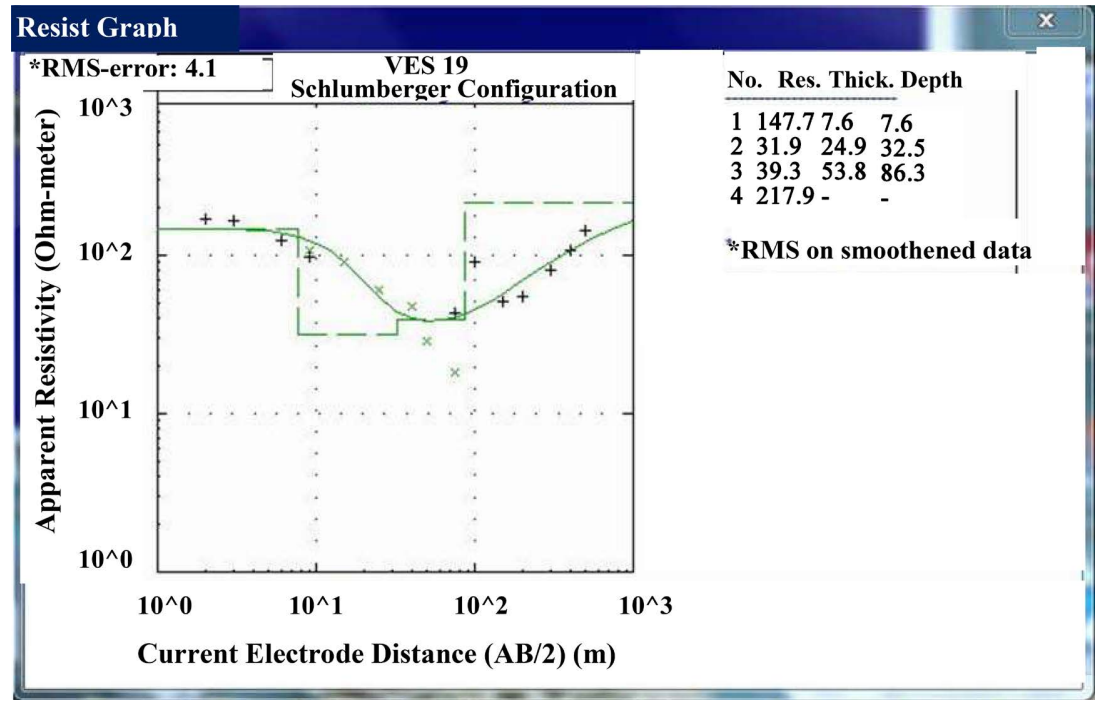

Figure 6. Interpretation curve for VES 19. 


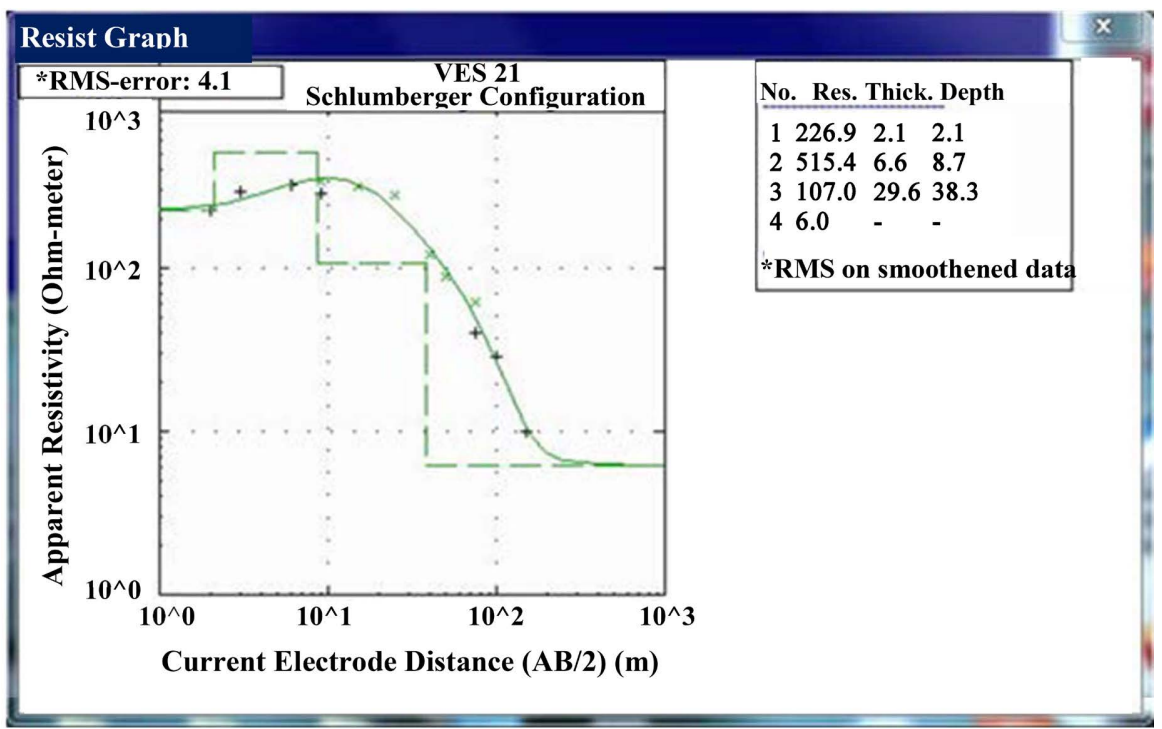

Figure 7. Interpretation curve for VES 21.

was able to transform, model the values to obtain a best fit relation to the field data. Assumption that the earth consists of uniform layers, separated by horizontal interfaces was noted in the interpretation of the resistivity sounding. The parameters obtained from the modelling are, the number of layers, apparent resistivity values for each layer, and thickness for each layers. Within the area of study which is composed of more than three layers of resistivity (Figures 4-7) $\rho_{1}$, $\rho_{2}, \rho_{3}$ and thicknesses $h_{1}, h_{2}$, and $h_{3}=\infty$ the geoelectric section is described according to the relation between their resistivity values of $\rho_{1}, \rho_{2}, \rho_{3}$. This gave rise to different types of geo-electric curves such as H-type $\left(\rho_{1}>\rho_{2}<\rho_{3}\right)$, A-type $\left(\rho_{1}<\rho_{2}<\rho_{3}\right)$, K-type $\left(\rho_{1}>\rho_{2}<\rho_{3}\right)$, and Q-type $\left(\rho_{1}>\rho_{2}>\rho_{3}\right)$., However, in general for more than three layers, the n-layer section is described by $(\mathrm{n}-2)$ letters. Figures 4-7 are the representative VES curves generated from the resistivity data acquired.

\subsection{Results}

Data analyses were conducted using both apparent resistivity and borehole data. Results obtained from the interpretation and data analysis include depth to apparent resistivity curve and 2D map of the aquifer zones. Results show that the apparent resistivity of the aquiferous zones varied from relatively low values (20.55 ohm meter to $153.451 \mathrm{ohm}$-meter) to high values (292.1 ohm-meter to $427.8 \mathrm{ohm}$ meter). The low resistivity values in these areas suggest the possibility of weathered shales with the presence of groundwater. The results from the modelled resistivity data reveal that VES curves obtained across the study area vary from 3 layer curves to 5 layer curves. The 4 layer curves are highest in occurrence as seen in Figures 5-8. The classification of the different curves types shows the following curve types in the study area, viz; HA and KQ with the highest occurrence (3 each). The rest of the curve types such as (KQQ, QHK, $\mathrm{HK}, \mathrm{QQ}, \mathrm{KH}, \mathrm{QQH}$,$) appeared twice each and (\mathrm{HKH}, \mathrm{KHKH}, \mathrm{KQH}, \mathrm{HKQ}$, 
HAK, AK, Q, A) appeared once each. Table 3 presents the curve types and their frequencies and percentages.

Table 3. Curve types in the study area.

\begin{tabular}{ccc}
\hline Curve type & Frequency & Percentage (\%) \\
\hline HA & 3 & 11.53 \\
KQ & 3 & 11.53 \\
KQQ & 2 & 7.69 \\
QHK & 2 & 7.69 \\
HK & 2 & 7.69 \\
QQ & 2 & 7.69 \\
KH & 2 & 7.69 \\
QQH & 2 & 7.69 \\
HKH & 1 & 3.85 \\
KHKH & 1 & 3.85 \\
AK & 1 & 3.85 \\
HKQ & 1 & 3.85 \\
HAK & 1 & 3.85 \\
KQH & 1 & 3.85 \\
Q & 1 & 3.85 \\
A & 1 & 3.85 \\
\hline & 1 & \\
\hline & 1 & 2 \\
\hline
\end{tabular}

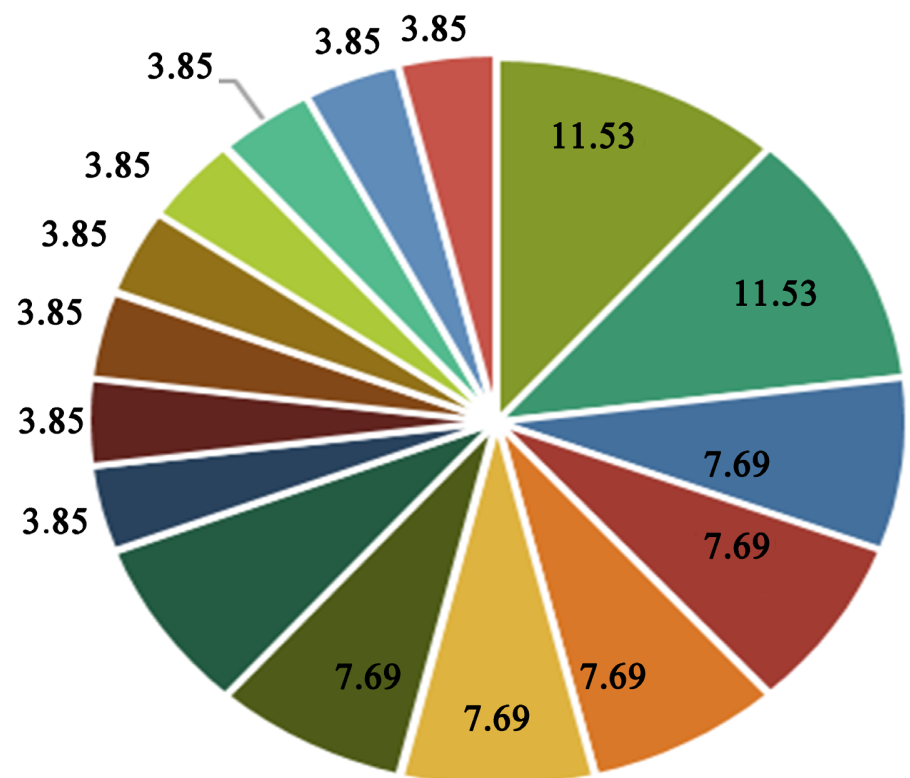

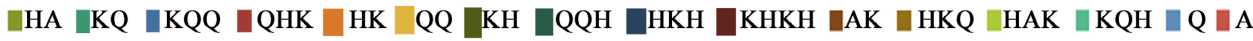

Figure 8. VES curve types and percentage distribution of frequencies in the study area. 


\subsection{Depth and 2D Resistivity Models}

Further $2 \mathrm{D}$ resistivity model was done using geospatial software, ArcGIS to model the variations in the geospatial variation in the apparent resistivity in the area to infer the surface-wide distribution of aquifer in the areas at given depth.

The depth and resistivity models of the study are shown in Figure 9 and Figure 10 respectively. The depth model shows colour-coded relative depths to the potential aquifers in the area. The blue colours shows areas with depth ranges from 10 to $20 \mathrm{~m}$. Groundwater potential in the area is indicated by the blue colour (deeper potential) at the depths of $40 \mathrm{~m}$ in towns such as New Haven, Trans-Ekulu, Nike, Nowas, Uwani, Enugu South, Awkunawnaw, etc. and at One Day, Garki at the depth of $70 \mathrm{~m}$ to $90 \mathrm{~m}$. However, majority of the study area including areas such as the Ugwu-Aji, Ngwo, Ogui Lauout, Ogui Layout hold shallow water at depth of $20-30 \mathrm{~m}$ in the weathered shale. These areas are

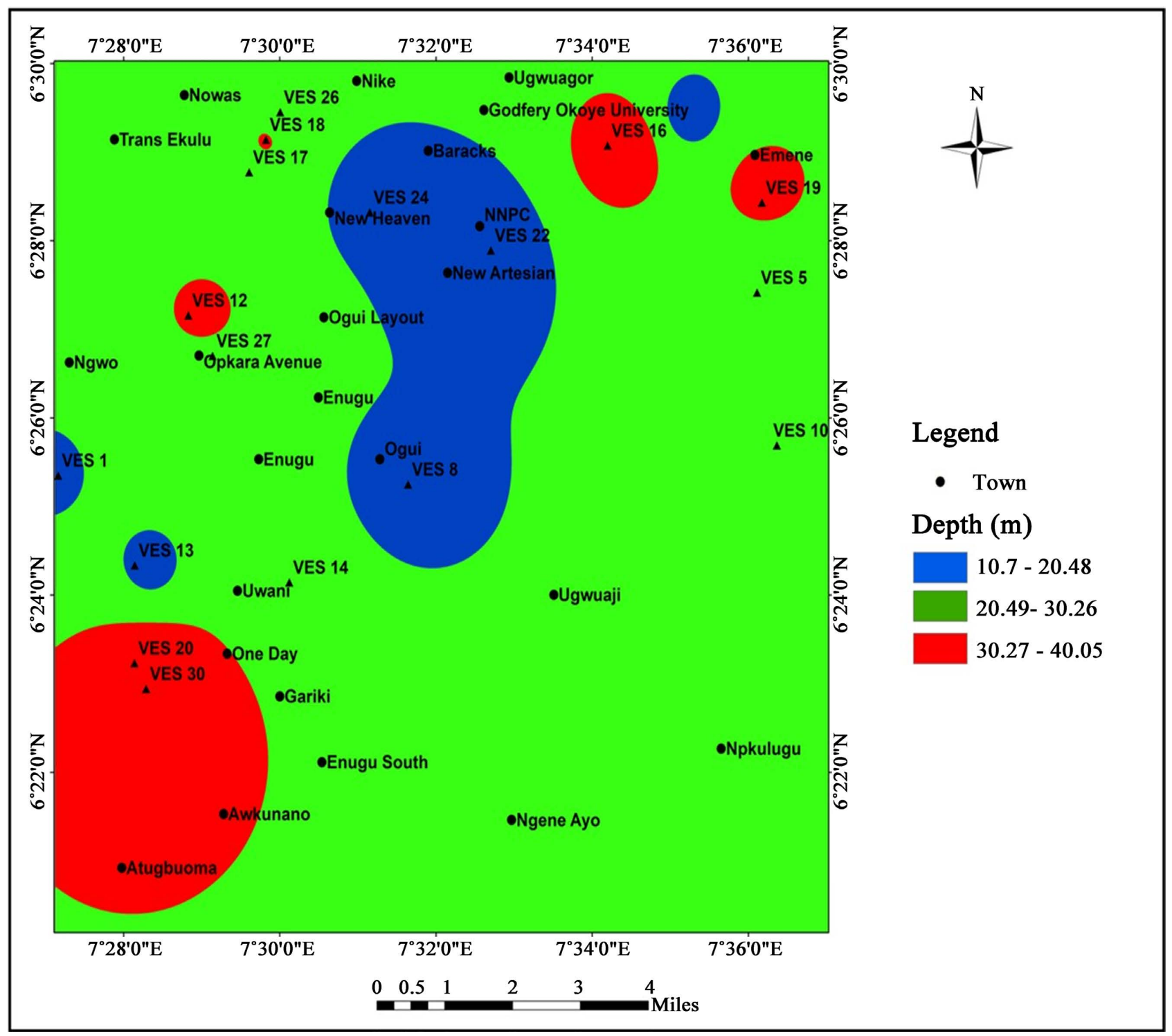

Figure 9. Depth model of aquiferous zones in the study area. 


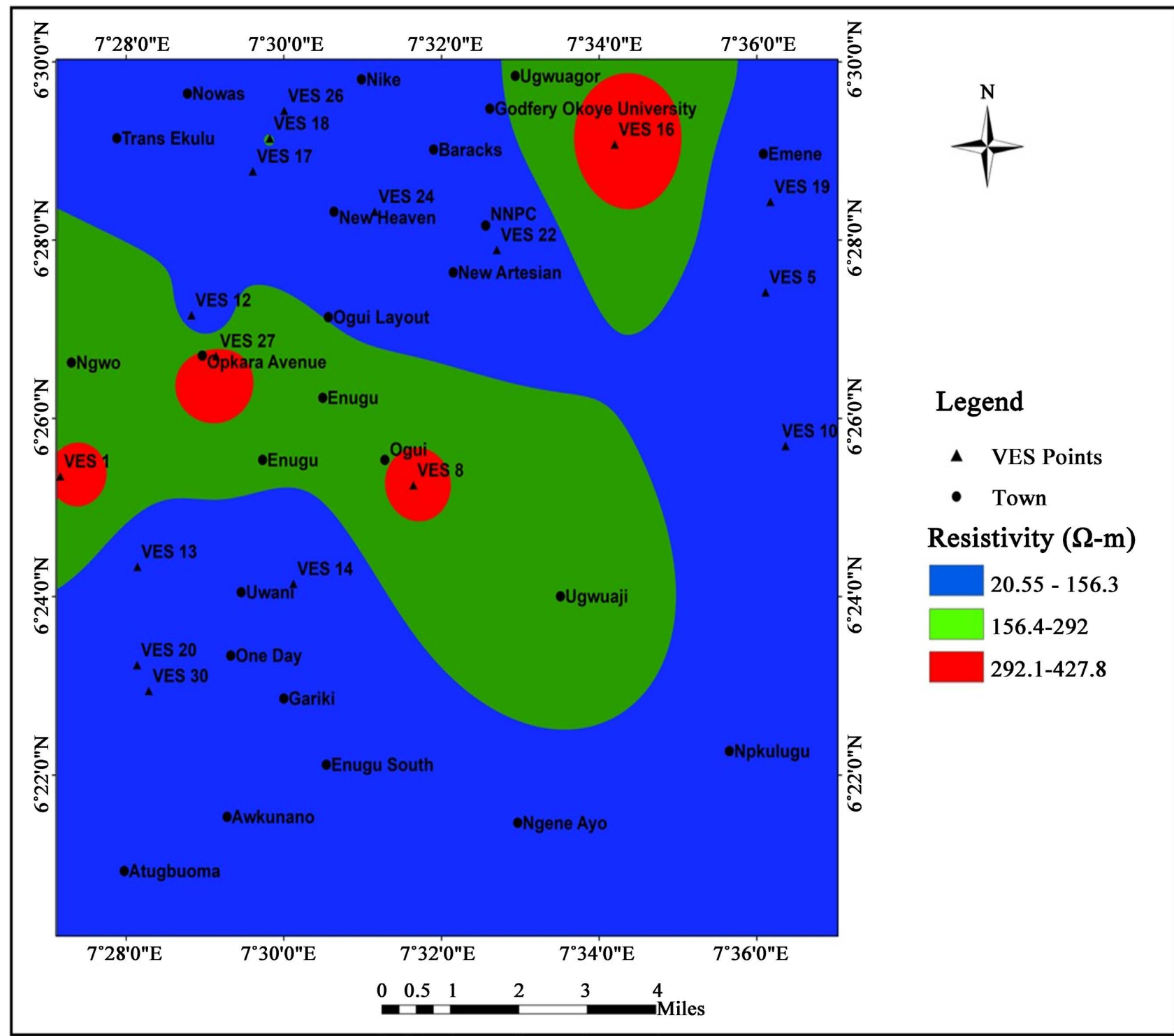

Figure 10. Resistivity model of the study area.

colour-coded green in Figure 9. Figure 10 shows the resistivity model of the study area. Areas such as Ogui, Okpara Avenue and areas within VES 1, VES 8 and VES 16. These areas are colou-coded red. The area is underlain by rocks with resistivity range of 292 - 420 ohm-meter. Medium range areas were colour-coded with green coloour. The areas include Ugwuogor, Ngwo, Ogui, Ugwuaji and eh surrounding areas. The least resistive areas at this $40 \mathrm{~m}$ depth were interpreted for the areas that were colour-coded blue colour. The areas underlain by these properties include Nowas, Nike, Trans Ekulu, NNPC filling station area, New Artisan, Emene, One day layout, Garki, Akunawnaw and Atugbuoma areas.

Correlation carried to evaluate the relationship between the different horizons were obtained from the resistivity and some nearby borehole data in the area. Figure 11 shows the correlation of the VES data along a cross section. The correlation established that the good saturated zones were correlatable across the Northwest 


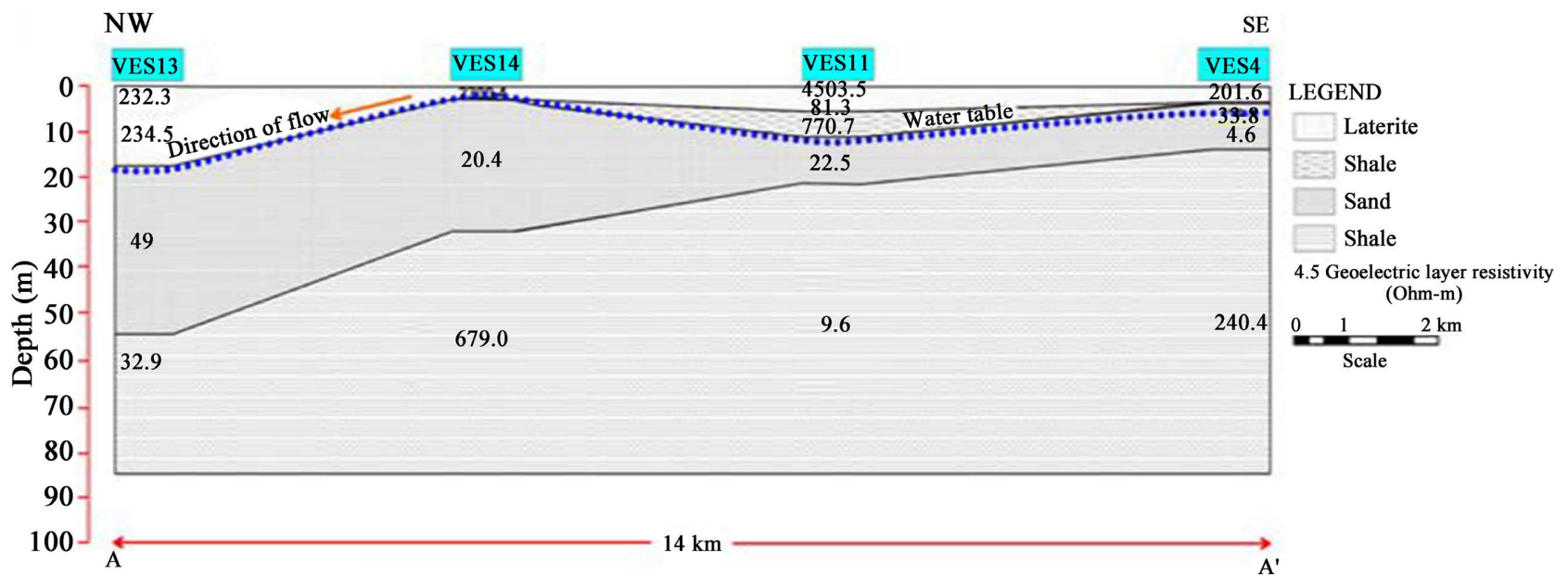

Figure 11. The correlation of the VES data along the cross section A-A-1

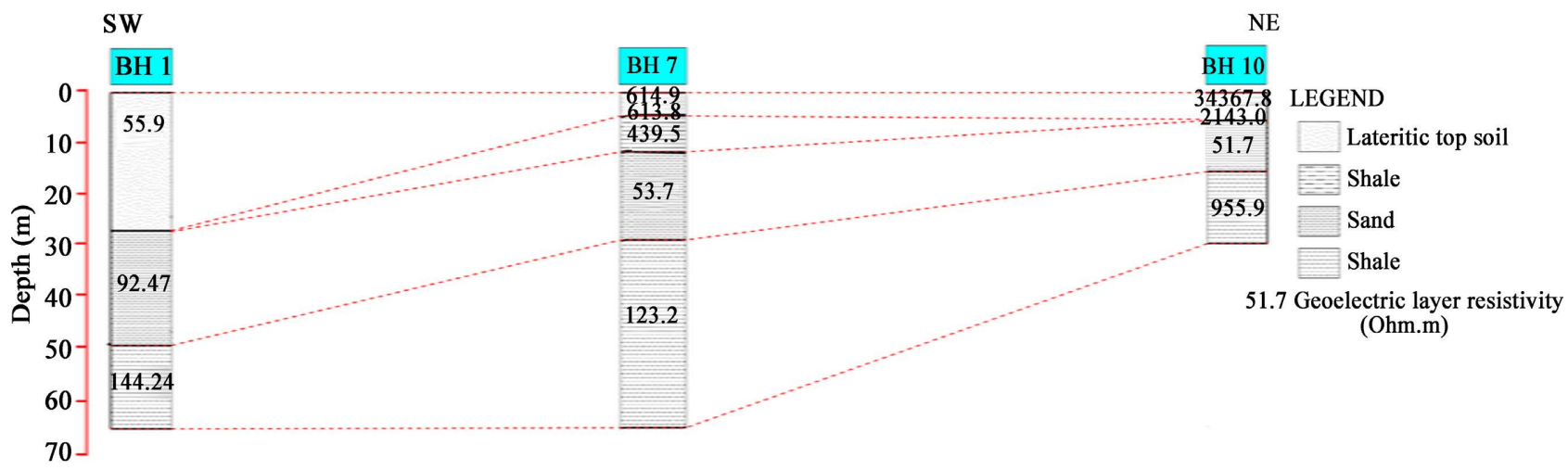

Figure 12. Correlation of borehole 1 to VES 7 and VES 10 along A-A-1.

and southeast area of the study area, and vary in thickness from Northwest to South East.

Figure 12 shows the correlation of borehole 1 to VES 7 and VES 10 along the southwest and northeast section. The resistivity model here also shows the variation of resistivity across the study area. Deeper section at the Southwest areas collate to shallow areas at the Northeast areas.

\section{Conclusions}

The study shows that Enugu Area is essentially underlain by shales, which make prolific aquifer absent. However, the main water resource lies within the weathered shale at shallow levels, between 40 to $70 \mathrm{~m}$ in some places. The vertical electrical sounding results gave dominantly 4 geoelectric layers, corresponding underlying rocks comprising of weathered top soil, weathered shale, shale, saturated shale and sandy shale. VES points probed within the horizon, not all the delineated areas is prolific. These aquifers exist at different depths within $40 \mathrm{~m}$ horizon. In areas such as Garki and One Day layout, slightly deeper aquifers exist in the layer with intercalation of sandstone. The values of the resistivity of the aquifer range from $20.55 \Omega \mathrm{m}$ to $427.8 \Omega \mathrm{m}$ at shallow layers. However, below 40 
$\mathrm{m}$ around $70 \mathrm{~m}$ to $90 \mathrm{~m}$ and from VES and Borehole data, saturated aquifers which can serve the domestic purposes of the inhabitants around Gariki can be located. Hence future groundwater exploration should concentrate on areas with greater depth of $70 \mathrm{~m}$ to $90 \mathrm{~m}$ around Garki and One day Layout. Also, sandstone bed at the deeper section at Nike area, also provides good groundwater within the area to provide enough water supply through moderately deep well to domestic use in the area.

Groundwater potential in the area is at a relatively shallow depth of $40 \mathrm{~m}$ in areas such as New Haven, Trans-Ekulu, Nike, Nowas, Uwani, Enugu South, Awkunawnaw. Deeper groundwater potential exists isolated zones, especially at One Day Layout, Garki and Nike areas at the depth of $70 \mathrm{~m}$ to $90 \mathrm{~m}$. However, majority of the study areas including areas such as the Ugwu-Aji, Ngwo, Ogui Lauout, Ogui hold shallow water at depth of $20-30 \mathrm{~m}$ in the weathered shale. Resistivity values that range from 292 - 420 ohm-meter are found at Ogui, Okpara Avenue as seen at VES 1, VES 8 and VES 16. Medium range areas include Ugwuogo, Ngwo, Ogui, Ugwuaji and the surrounding areas. The least resistive areas at this $40 \mathrm{~m}$ depth were Nowas, Nike, Trans Ekulu, NNPC filling station area, New Artisan, Emene, One day layout, Garki, Akunawnaw and Atugbuoma areas. Therefore with careful selection of borehole point, moderate to good quantity of water to serve domestic purpose can be achieved in the areas. Residents at these areas are advised to drill deeper to obtain good aquifer yield at the above areas instead of relying on shallow zones which are less saturated and do not yield reasonable quantity of water due to the impermeable nature of the underlying rock, the shale.

\section{Acknowledgements}

The authors express their thanks to the technical team from the Department of Geology who provided the technical support during the field data acquisition.

\section{Conflicts of Interest}

The authors declare no conflicts of interest regarding the publication of this paper.

\section{References}

[1] Bouwer, F.L. (1978) Groundwater Hydrology. Mac Graw Hill, New York, 149 p.

[2] Paranis, D.S. (1986) Principles of Applied Geophysics. 4th Edition, Chapman and Hall, New York, London.

[3] Telford, W.M., Geldart, L.P. and Sheriff R.E. (1991) Applied Geophysics. Cambridge University Press, USA, 860 p. https://doi.org/10.1017/CBO9781139167932

[4] Loke, M.H. (2011) Electrical Resistivity Surveys and Data Interpretation. In: Gupta, H., Ed., Encyclopedia of Solid Earth Geophysics, 2011 Edition, Springer, Dordrecht, 276-283. https://doi.org/10.1007/978-90-481-8702-7 46

[5] Nwajide, C.S. (2005) Anambra Basin of Nigeria: Synoptic Basin Analysis as a Basis for Evaluation of Its Hydrocarbon Prospectivity. In: Okogbue, C.O., Ed., Hydro- 
carbon Potentials of the Anambra Basin: Geology, Geochemistry and Geohistory Perspectives, Great AP Express Publisher Limited, Nsukka, 83-110.

[6] Sundararajan, N., Al-Garni, M.A., Ramabrahmam, G. and Yasala, S. (2007) A Real Spectral Analysis of the Deformation of a Homogenous Electric Field over a Thin bed-A Hartley Transform Approach. Geophysics Prospecting, 55, 901-910. https://doi.org/10.1111/j.1365-2478.2007.00650.x

[7] Massoud, U., Santos, F., Khalil, M., Taha, A. and Abbas, A.M. (2010) Estimation of Aquifer Hydraulic Parameters from Surface Geophysical Measurements: A Case Study of the Upper Cretaceous Aquifer at the Central Sinai, Egypt. Hydrogeology Journal, 18, 699-710. https://doi.org/10.1007/s10040-009-0551-y

[8] Ezeh, C.C. and Ugwu, G.Z. (2010) Geoelectrical Sounding for Estimating Groundwater Potential in Nsukka L.G.A. Enugu State, Nigeria. International Journal of Physical Sciences, 5, 415-420.

[9] Farid, A., Jadoon, K.Z., Akhter, G., Asim Iqbal, M. (2013) Hydrostratigraphy and Hydrogeology of the Western Part of Maira Area, Khyber Pakhtunkhwa, Pakistan: A Case Study by Using Electrical Resistivity. Environmental Monitoring and Assessment, 185, 2407-2422. https://doi.org/10.1007/s10661-012-2720-Z

[10] Okonkwo, A. and Ezeh, C.C. (2013) Aquifer Hydraulics and Delineation of Groundwater Quality Zones Using Electrical Resistivity Method at Oduma and Environs in Enugu State, Southeastern Nigeria. International Research Journal of Geology and Mining, 3, 31-39.

[11] Fadele, S.I., Sule, P.O. and Dewu, B.B.M. (2013) The Use of Vertical Electrical Sounding (VES) for Groundwater Exploration around Nigerian College of Aviation Technology (NCAT), Zaria, Kaduna State, Nigeria. The Pacific Journal of Science and Technology, 13, 549-555.

[12] Umeh, V.O., Ezeh, C.C. and Okonkwo, A.C. (2014) Groundwater Exploration of Lokpaukwu, Abia State Southeastern Nigeria, Using Electrical Resistivity Method. International Research Journal of Geology and Mining, 4, 76-83. https://doi.org/10.14303/irigm.2014.019

[13] Chukwuma, E., Anozoba, D., Chukwuma, G.O. and Chinwuko, C.E. (2015) Determination of Aquifer Characteristics from Geo-Electrical Sounding Data in Parts of Anambra State, Nigeria. International Journal of Innovation and Applied Studies, 11, 832-843.

[14] Obiora, D.N., Ibuot, J.C. and George, J.J. (2015) Evaluation of Aquifer Potential, Geoelectric and Hydraulic Parameters in Ezza North, Southeastern Nigeria, Using Geoelectric Sounding. International Journal of Environmental Science and Technology, 13, 435-444. https://doi.org/10.1007/s13762-015-0886-y

[15] Osele, C.E., Onwuemesi, A.G., Anakwuba, E.K. and Chinwuko, A.I. (2016) Application of Vertical Electrical Sounding (VES) for Groundwater Exploration in Onitsha and Environs, Nigeria. International Journal of Advanced Geosciences, 4, 1-7. https://doi.org/10.14419/ijag.v4i1.5594

[16] Okeke, J.P, Ezeh, C.C. and Okonkwo, A.C (2017) Geoelectrical Sounding for the Determination of Groundwater Prospects in Awgu and Its Environs, Enugu State, Southeastern Nigeria. IOSR Journal of Applied Geology and Geophysics, 5, 14-22.

[17] Adeoti, L., Adegbola, R.B., Iya, A., Oyeniran, T. and Ayuk, M.A. (2018) Geoelectrical Assessment of Groundwater Potential at Ewuloja and Its Environs in Simawa Area, Southwestern Nigeria. Nigerian Journal of Technological Development, 15, 39-49. https://doi.org/10.4314/njtd.v15i2.2

[18] Mgbeojedo, T.I., Al-Naimi, L.S., Nosiri, O.P., Selemo, A.O. and Almakki, M.T. 
(2018) Evaluation of the Aquifer Characteristics of Some Parts of Orsu, South-Eastern Nigeria. International of Modern Engineering Research, 8, 44-54. https://www.researchgate.net/publication/349711893.

[19] Okonkwo, A. and Ezeh, C.C. (2019) Surface Geoelectrical Sounding for the Determination of Groundwater Potential Zones in Anambra State, Nigeria. NMGS International Conference "Coal City 2019", Enugu State, 17-22 March 2019, 17-22.

[20] Loke, M.H. and Barker, R.D. (1996) Rapid Least Squares Inversion of Apparent Resistivity Pseudo-Sections by a Quasi Newton Method. Geophysical Prospecting, 44, 131-152. https://doi.org/10.1111/j.1365-2478.1996.tb00142.x 